\title{
Genetic variation in two conserved local Romanian pig breeds using type 1 DNA markers
}

\author{
Daniel C. Ciobanu ${ }^{\mathrm{a}, \mathrm{b}, *}$, Andrew E. DAY ${ }^{\mathrm{c}}$, \\ Alexandru NAGY ${ }^{\text {d, }}$, Richard WALES ${ }^{c}$, Max F. RothSCHILD ${ }^{\mathrm{b}}$, \\ Graham S. Plastow ${ }^{\mathrm{c}}$ \\ a Animal Genetics Unit, University of Agricultural Sciences and Veterinary \\ Medicine, 3400 Cluj Napoca, Romania \\ ${ }^{b}$ Department of Animal Science, 2255 Kildee Hall, Iowa State University, Ames, \\ IA 50011, USA \\ ${ }^{\mathrm{c}}$ PIC International Group, Fyfield Wick, OX13 5NA, UK \\ ${ }^{d}$ Agricultural Research Station of Turda, Romania
}

(Received 7 August 2000; accepted 20 February 2001)

\begin{abstract}
Analysis of the genetic variation of an endangered population is an important component for the success of conservation. Animals from two local Romanian pig breeds, the Mangalitsa and Bazna, were analysed for variation at a number of genetic loci using PCRbased DNA tests. Polymorphism was assessed at loci which 1) are known to cause phenotypic variation, 2) are potentially involved in trait differences or 3) are putative candidate genes. The traits considered are disease resistance, growth, coat colour, meat quality and prolificacy. Even though the populations are small and the markers are limited to specific genes, we found significant differences in five of the ten characterised loci. In some cases the observed allele frequencies were interesting in relation to gene function and the phenotype of the breed. These breeds are part of a conservation programme in Romania and marker information may be useful in preserving a representative gene pool in the populations. The use of polymorphisms in type 1 (gene) markers may be a useful complement to analysis based on anonymous markers.
\end{abstract}

pig / genetic diversity / local breeds

\section{INTRODUCTION}

Domestic animals have been an important element of human development, satisfying needs for food, clothing and power. About 40 different species have been used, and humans have produced some 4500 breeds, known today as the "world's animal genetic resources" [2]. More than 30\% of these breeds are now

\footnotetext{
* Correspondence and reprints
}

E-mail: dciobanu@iastate.edu 
in danger of extinction and others are threatened by inefficient utilisation [2]. In Europe, at the European Association for Animal Production-Animal Genetic Data Bank, a total of 1029 breeds of cattle, sheep, goats, pigs, horses, poultry and donkeys are recorded and more than $40 \%$ are considered to be "at risk" [33].

The professional preservation of domestic animals is a relatively recent endeavour. In the last decade, the increased popularity of this idea could be observed everywhere and has been supported by private charity organisations or governmental programmes. In Europe, there are more than 360 active conservation programmes underway in many different countries [33]. Ruane provided a set of criteria to be considered when choosing a specific breed for a conservation programme [30]. Degree of endangerment and genetic uniqueness of the breed are two of seven listed essential criteria. However, possessing traits of current or future economic and scientific importance for breed survival can be considered the dominant criterion, although the cultural and historical value of these traits should also be considered as extremely important.

There are opportunities to conserve rare livestock in Romania although it will be a difficult task as the remaining populations are relatively small. In pigs there are two rare breeds: the Red Mangalitsa and Bazna.

The Mangalitsa is one of the old type breeds, originating several centuries ago as a result of crossing between European and Asian primitive pigs. The Mangalitsa has a similar origin to other Mediterranean breeds produced at the same time, but originates from the Balkan region where there was less crossing with Asian pigs. The Sumadija pig from the Morava and Sava Valleys and the Syrmia pig from Slavonia are considered to be possible ancestors of the Mangalitsa [22].

Mangalitsa was introduced into Romania from Serbia in the 19th century (Transylvania - 1833; Oltenia, 1860) [10]. In this region there were a number of varieties, selected and bred by the great landowners. The main features of these pigs were curly hair, thick backfat, palatable meat and disease resistance. In Romania, all of the Mangalitsa varieties (blond, red, black and swallow-bellied types) were originally present. However, only the red variety has survived. This variety was established by crosses between the Salonta pig and the blond Mangalitsa [1]. The Salonta pig or "Red pig" was bred in the Eastern part of Hungary and also in Transylvania and was produced from crosses between Roman and wild pigs $[1,10]$. Pigs from this breed were well regarded and were prize winners in the Paris (1855) and Vienna (1873) exhibitions. But in spite of these successes, these pigs disappeared quickly after being absorbed into the Mangalitsa [1].

The Bazna breed was produced by crossing the Mangalitsa with the Berkshire. In 1872 a breeder used a unique Berkshire boar for mating with Mangalitsa sows (blond type) in the village of Bazna (Sibiu county, Romania) [10]. The pigs resulting from these crosses retained the "superior" 
traits from both breeds and formed the basis of the new breed. Their manner of breeding following the initial crossing is unknown, but is thought to have been uncontrolled. The local breeders used inbreeding to improve and to maintain the superior traits of these pigs. Bazna pigs were regarded as superior to the Mangalitsa in prolificacy, quality of carcass and fertility [10]. They were also well suited to the conversion of low quality food and were regarded as hardy and resistant to diseases. An important feature of the Bazna breed was also its black colour and white belt. After 1900, some Berkshire boars were imported from England to further improve the Bazna. The breed became very popular, resulting in its spread to almost all regions of Transylvania. However, the number of boars were insufficient, and there are some reports of imput from other breeds (the Yorkshire in the Sibiu County, Mangalitsa in the Fagaras area, etc.). Beginning in 1959 at the nucleus herd at Turda, Sattelschwein were imported from Germany to improve the breed.

Both breeds are in a national conservation programme at the Agricultural Research Station of Turda. Nevertheless, today there are less than 50 sows from the Mangalitsa and 100 from the Bazna at Turda. Both breeds are appreciated for the high quality of the meat, which is used for preparing special local products. Recently, some pig units started to use the Mangalitsa in schemes involving the Duroc, the final product being used in preparing a traditional old type bacon, very much appreciated by the market.

In order to help with the conservation effort and breed promotion, several research projects were initiated to phenotypically characterise these breeds [24$26]$ and genetic characterisation has begun to complement these efforts.

Microsatellite markers have been recommended by the FAO for the characterisation of genetic distance of animal breeds [3]. However, the relationship between variability at neutral marker loci, such as microsatellite markers, and adaptation or individual fitness is still unclear [30]. Thus it might be useful to consider sequence differences (polymorphisms) within genes for the purposes of genetic differentiation. It is also known that in domestic animals the important phenotypic differences between breeds may be due to differences in a few loci (as illustrated by coat colour, see $[11,15]$ ). For these reasons, the use of major genes instead of neutral markers should be considered as an interesting alternative for the measurement of genetic diversity for the purposes of establishing new breeding stock and/or to cryopreserve a pool of the germplasm. This study outlines the result of genetic analyses using data from a number of type 1 DNA markers (polymorphisms in genes) analysed in the Red Mangalitsa and Bazna populations from Romania. Ten genes were chosen for the study, three of which (CRC1, FUT1 and MC1R) have polymorphisms known to change gene function and phenotype, three (ESR, $P R L R$ and $M C 4 R$ ) have been found to be associated with phenotypic variation and four (NRAMP1, CAST, LEP and LEPR) are potential candidate genes [27]. 
The traits considered were prolificacy, growth, disease resistance, meat quality and coat colour.

\section{MATERIALS AND METHODS}

A total of 40 individual hair samples from Red Mangalitsa and 62 from Bazna pigs were collected from animals at the Agricultural Research Station of Turda, Romania. In the case of the Bazna breed, this herd is the only nucleus herd in the world. The Red Mangalitsa population of Turda is probably the most representative in the world.

The DNA markers, polymorphic sites and traits associated with them are listed in Table I. In order to detect the polymorphisms we used PCR-RFLP (Polymerase Chain Reaction - Restriction Fragment Length Polymorphism) procedures. The DNA preparation, primer sequences and reaction conditions have been described previously [7,9,15,16,21,29,32,34,36,41].

An additional marker not previously published, developed by Rothschild and Vincent, was used to analyse a polymorphism in the leptin receptor gene (LEPR) a candidate gene thought to control fat deposition. Pig-specific PCR primers were used to amplify a 378 bp (base pair) fragment covering exon 20 . Following amplification of genomic DNA, the PCR products were digested with $\mathrm{MboI}$ and electrophoresed in $2 \%$ agarose gel. Two alleles were detected: allele A (339 and $39 \mathrm{bp)}$ ) and B (282, 57 and $39 \mathrm{bp})$. For each locus we scored two alleles except the NRAMP1 (Natural Resistance-Associated Macrophage Protein 1) locus where we found three alleles. Three biallelic polymorphisms were analysed at the $M C 1 R$ gene.

Using gene frequencies for the polymorphic loci in both breeds, we applied an $\chi^{2}$ contingency test, where appropriate, in order to evaluate the genetic differentiation between the Bazna and Mangalitsa populations, according to the marker data (Tab. II).

\section{RESULTS}

\subsection{DNA markers associated with meat quality}

\subsubsection{Calcium Release Channel (CRC1)}

The halothane or stress gene, as it was first called, was the first practical application of a DNA test for a major gene in pig breeding [9]. A single point mutation in the calcium release channel gene, when present in the homozygous condition, is responsible for porcine stress syndrome (PSS, malignant hyperthermia) and also results in increased muscling and less backfat (possibly as a result of close linkage to another gene). 


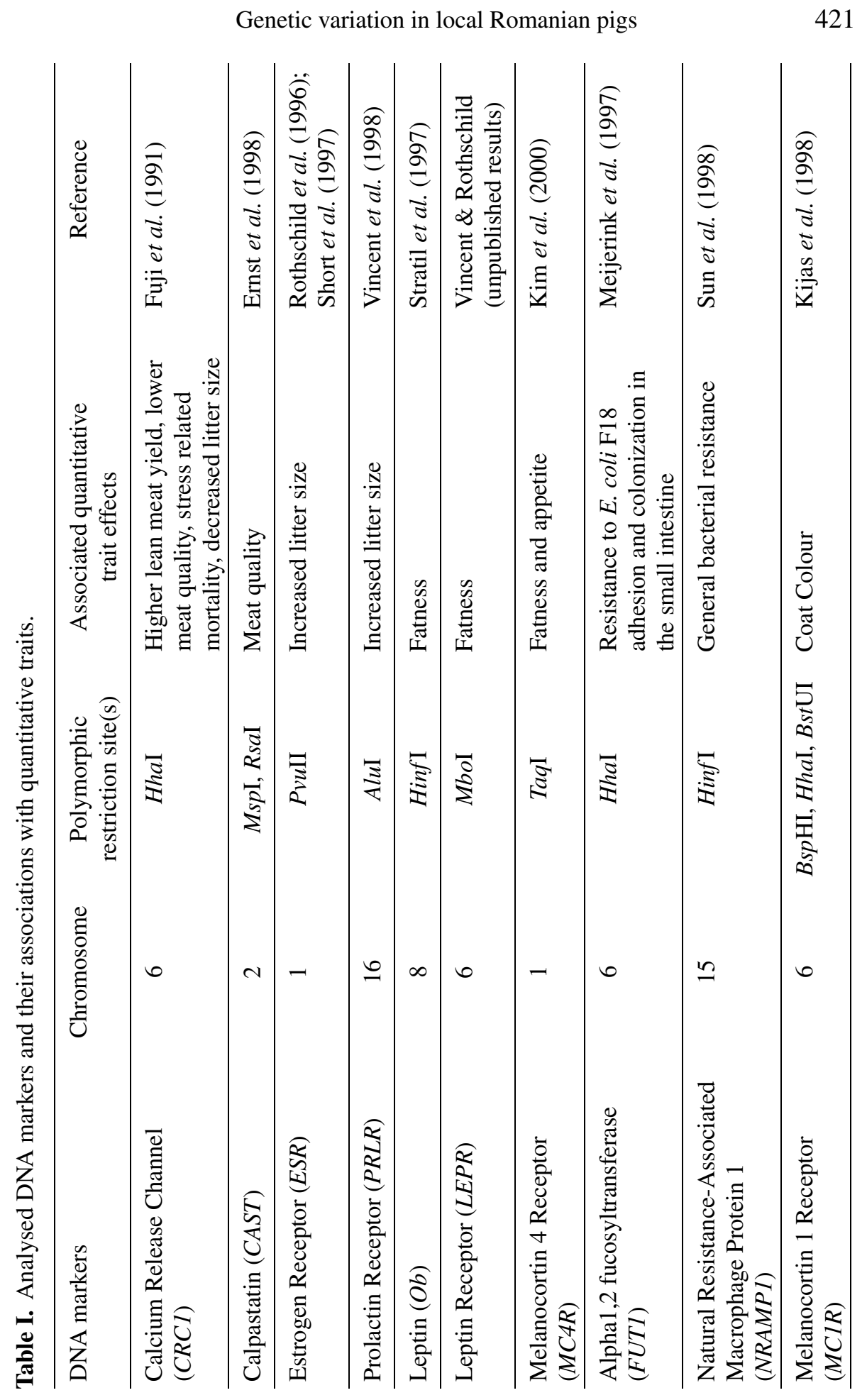


Table II. Allelic frequencies of the analysed loci and genetic differences among the populations using $\chi^{2}$ contingency test.

\begin{tabular}{|c|c|c|c|c|}
\hline \multirow[t]{2}{*}{ DNA markers } & \multirow[t]{2}{*}{ Allele } & \multicolumn{2}{|c|}{ Frequency } & \multirow[t]{2}{*}{$\chi^{2}$} \\
\hline & & Mangalitsa & Bazna & \\
\hline $\begin{array}{l}C R C 1 \\
\text { Calcium Release Channel }\end{array}$ & $N$ & 1.00 & 1.00 & NT \\
\hline $\begin{array}{l}\text { CAST } \\
\text { Calpastatin/MspI }\end{array}$ & C & 0.55 & 0.45 & $1.88 \mathrm{~ns}$ \\
\hline $\begin{array}{l}\text { CAST } \\
\text { Calpastatin /RsaI }\end{array}$ & $E$ & 0.66 & 0.53 & $2.76 \mathrm{~ns}$ \\
\hline $\begin{array}{l}\text { ESR } \\
\text { Estrogen Receptor }\end{array}$ & $B$ & 0.00 & 0.04 & NT \\
\hline $\begin{array}{l}P R L R \\
\text { Prolactin Receptor }\end{array}$ & $A$ & 0.11 & 0.49 & $32.25^{* * *}$ \\
\hline $\begin{array}{l}\text { LEP } \\
\text { Leptin } \\
\end{array}$ & $T$ & 1.00 & 0.97 & NT \\
\hline $\begin{array}{l}\text { LEPR } \\
\text { Leptin Receptor }\end{array}$ & $B$ & 0.93 & 0.80 & $5.45^{*}$ \\
\hline $\begin{array}{l}M C 4 R \\
\text { Melanocortin } 4 \text { Receptor } \\
\end{array}$ & $A$ & 0.09 & 0.45 & $27.92^{* * *}$ \\
\hline $\begin{array}{l}\text { FUT1 } \\
\text { Alpha1,2 fucosyltransferase }\end{array}$ & $A$ & 0.69 & 0.30 & $30.31^{* * *}$ \\
\hline $\begin{array}{l}\text { NRAMP1 } \\
\text { Natural Resistance- } \\
\text { Associated Macrophage Protein } 1\end{array}$ & $\begin{array}{l}A \\
B \\
C\end{array}$ & $\begin{array}{l}0.33 \\
0.67 \\
0.00\end{array}$ & $\begin{array}{l}0.13 \\
0.83 \\
0.04\end{array}$ & $10.62^{* *}$ \\
\hline
\end{tabular}

NT $=$ not tested; n.s.: $P>0.05 ;{ }^{*}: P \leq 0.05$; ** $P \leq 0.01$; **: $P \leq 0.001$.

Degree of freedom (d.f.) $=1$. For NRAMPI allele $\mathrm{C}$ not tested due to lack of numbers per cell.

Several reports demonstrate the absence of the "stress gene" in the local pig populations from Central and Eastern Europe (e.g. [31]) and this was the case for both breeds in this experiment. In Transylvania the consumption of pig backfat was a tradition. For this reason breeders appreciated pigs with a medium amount of backfat rather than selecting for leanness. This preference would have acted as a barrier for the introgression of the $H A L$ gene.

\subsubsection{Calpastatin (CAST)}

Calpastatin is a specific, endogenous inhibitor of the calcium-activated proteases known as calpains. This system is involved in some growth and 
metabolic processes [7]. There is evidence for the decreasing activity of CAST with age and a significant higher activity in obese pigs compared with lean pigs [18]. Ernst et al. [7] reported MspI, RsaI and Hinf I RFLPs at the porcine CAST locus, pointing it out as a possible candidate gene for muscle protein accretion and pork quality.

In this study two of the polymorphisms ( $M s p \mathrm{I}$ and $R s a \mathrm{I}$ ) were used. There were small non-significant differences between the gene frequencies of the two breeds $(P>0.05)$ (Tab. II). For the MspI site, the result for both breeds is similar to that reported for some European breeds (Yorkshire, Large White) but is different from Chinese breeds where allele $C$ is fixed in the Meishan and Fengjing [7]. In the case of the RsaI site the highest frequencies for allele $E$ (above 0.70) were found in the Duroc, Hampshire and Landrace [7]. The Mangalitsa has a similar frequency $(0.66)$ to that found in the Berkshire - a breed known for good meat quality - and higher than that of the Bazna breed (0.53). However, all of the frequencies are very similar. In the study of Ernst et al. [7] the genotype DDEE is the most prevalent in the Landrace (0.72), Pietrain (0.67) and Duroc (0.63). This genotype was absent in Chinese breeds [7] and is relatively low in the Bazna (0.38) and Mangalitsa (0.27) breeds. It should be noted that the intermediate frequencies of these markers make them suitable as candidates for future association analyses for meat quality in these breeds.

\subsection{DNA markers associated with prolificacy}

\subsubsection{Estrogen Receptor (ESR)}

The marker used in the ESR gene was shown to have a significant effect on litter size in some breeds and commercial populations [28,29,32]. The ESRB allele is predominant in the Chinese Meishan breed, known for its prolificacy and was also found in commercial dam lines of Large White origin [32]. It is assumed that it is derived from early importation of Chinese pigs into England prior to the 1800 s and crossbreeding with pigs that eventually became the Large White breed [6].

Mangalitsa and Bazna are fixed or close to fixation for allele $A$ of ESR, which is the unfavourable allele in terms of litter size (Tab. II). The prolificacy of Bazna is significantly superior to the Mangalitsa [25,26]. However, it is unlikely that this is associated with ESR as the beneficial allele is present at such low levels. The results suggest neither breed has much influence from Chinese breeds.

\subsubsection{Prolactin Receptor (PRLR)}

Prolactin (PRL) is an anterior pituitary hormone involved in different endocrine activities and is essential for reproductive success. This action is mediated 
by its receptor (PRLR) an important key regulator of mammalian reproduction. In knockout mice, lack of a functional allele produces multiple reproductive defects [23]. Results from 4 of 6 commercial lines suggested that $A$ allele is associated significantly with litter size [41].

The frequencies of the polymorphism scored for $P R L R$ are different between the breeds $(P<0.001)$ (Tab. II). It is possible, based on these limited results, that the superiority of Bazna regarding prolificacy $[25,26]$ could be related to the relative abundance of the $A$ allele in Bazna (0.49) compared with Mangalitsa (0.11).

\subsection{DNA markers associated with growth and fatness}

\subsubsection{Leptin (LEP)}

Leptin, is a hormone secreted by adipose tissue and it is a component of a system which controls fuel stores and energy balance at an optimum level [8]. A mutation in the leptin gene ( $L E P)$ is responsible for the obese phenotype of the ob/ob mouse [43]. Stratil et al. [34] found a PCR-RFLP polymorphism at the pig $O b$ locus (now called $L E P$ ), with two alleles, using the enzyme HinfI. The alleles are designated $C$ and $T$ according to the polymorphic base at position 3469 in the sequence according to Bidwell et al. [4].

Both breeds are fixed or close to fixation for allele $T$ of the $L E P$ polymorphism reported by Stratil et al. [34] (Tab. II). Bazna is a superior breed compared to Mangalitsa for carcass quality $[24,26]$. These breeds are relatively unimproved and so this might suggest that the other allele $(C)$ might be associated with a leaner genotype. However, Stratil et al. [34] reported the allele $C$ to be fixed in the very fat Meishan, and at low frequency in Landrace (0.04) and Hampshire (0.08). While this suggests that there may be not be an association of fatness with this polymorphism in pigs, the results of Jiang and Gibson [14] are also worth considering. They identified the same polymorphism in their study and analysed for evidence of an association with fatness by looking at allele frequencies in the extreme samples (leanest and fattest) in four populations of pigs. A significant difference was found for this polymorphism in a sample of Large White pigs. Interestingly the "fat allele" was allele $T$, which is more in line with the findings for Bazna and Mangalitsa. However, they were unable to find support for this association in a second sample from the same population. They speculate that the mutation may be in linkage disequilibrium with another mutation in the gene or region, although they suggest that this linkage disequilibrium would seem to be unique for the Large White breed [14].

\subsubsection{Leptin Receptor (LEPR)}

The LEPR is the high affinity receptor for leptin and was identified as a member of the cytokine family of receptors [37]. Mutation in leptin receptor gene results in an obese phenotype identical to that of $o b$ mice [20]. 
There are several polymorphisms reported in the pig $L E P R$ gene $[35,40]$. Vincent and Rothschild (unpublished results) found an $\mathrm{MboI}$ polymorphism where the $B$ allele is a candidate marker for fatness. They found that the $B$ allele was fixed in Meishan and at relative high frequency in Chester (0.94), Yorkshire (0.77) and Landrace (0.75).

Bazna, with a better carcass quality $[24,26]$ has a lower frequency for allele $B$ (0.80) compared to the Mangalitsa where this allele is more frequent (0.93) (Tab. II). The difference between the allele frequency of these populations is significant $(P<0.05)$. The $B$ allele may be closely linked to a causative mutation from the same gene or a different gene affecting the level of fatness.

\subsubsection{Melanocortin 4 Receptor (MC4R)}

Genetic data indicates that the melanocyte-stimulating hormone (MSH) and its receptor melanocortin-4 receptor (MC4R) are required for a response to an increased plasma leptin concentration in the weight gain process [8]. Several mutations in the $M C 4 R$ gene, both frameshift and nonsense are associated with dominantly inherited obesity in humans $[38,42]$. The inactivation of the $M C 4 R$ gene in the mouse has resulted in a maturity onset obesity syndrome, demonstrating the role of this gene in regulation of the energy balance [13].

In pigs, the $M C 4 R$ locus is another candidate for growth, appetite and fatness. Kim et al. [16] reported a missense mutation in the pig $M C 4 R$ gene that replaces an aspartic acid residue with asparagine in a conserved region of the protein. Based on an association study with more than 1500 records they found that one allele ( 2 - renamed $A$ in our study) was significantly associated with higher feed intake, higher levels of fat and faster growth. We now have experimental information to believe it is the causative mutation (Kim et al., unpublished results).

There is a significant difference in the allele frequencies between the two breeds $(P<0.001)$ (Tab. II). Bazna, with faster growth and more feed intake [10] has a higher frequency for allele $A(0.45)$ compared to the Mangalitsa (0.09). This marker may therefore explain some of the variation in appetite, growth and fatness in these breeds.

\subsection{DNA markers associated with disease resistance}

\subsubsection{Alpha 1,2 fucosyltransferase (FUT1)}

Oedema disease and post-weaning diarrhoea in swine are associated with the colonisation of the intestine with toxigenic Escherichia coli bacteria of various serotypes. The success of colonisation depends on specific binding between adhesive fimbriae and receptors on the enterocytes. Sequencing of the alpha$(1,2)$-fucosyltransferase gene $(F U T 1)$ in swine that are either susceptible or resistant to adhesion by F18 fimbriated $E$. coli revealed a mutation at basepair 
307 [21]. Analysis of this mutation showed close linkage with the locus controlling resistance and susceptibility to E. coli F18 adhesion (ECF18R). The frequencies of this polymorphism for FUT1 are also different between the breeds $(P<0.001)$ (Tab. II). Based on the Station medical reports (unpublished data), Mangalitsa is a breed more resistant to oedema disease and post-weaning diarrhoea. The frequency of the resistant allele in Mangalitsa (0.69) is higher than that of the Bazna (0.30) and therefore this gene may explain part of the observed difference in phenotype. Klukowska et al. [17] also reported a high frequency (0.63) of the "resistant gene" in the Zlotnicka Spotted breed when compared with animals of the Polish Landrace (0.22) and Large White (0.36) breeds. Zlotnicka Spotted is a dual fat-meat type breed originating from crosses of primitive long-eared and short-eared pigs and possibly with some share of English Large White. These results support the generally accepted belief that old local breeds could be an important resource of genes conferring resistance for different diseases.

\subsubsection{Natural Resistance - Associated Macrophage Protein 1 (NRAMP1)}

In the human and mouse the macrophage specific protein, encoded by the NRAMP1 gene, controls to some degree resistance and susceptibility to Salmonella and other antigenically unrelated bacteria [5,39]. Sun et al. [36] studied the NRAMPl gene as a potential candidate gene for controlling pig resistance to bacterial infection, and identified a polymorphism with three alleles using the restriction enzyme $\operatorname{Hinf} \mathrm{I}$.

The polymorphisms scored for NRAMPI genotypes are different in the two breeds (Tab. II). Mangalitsa has a higher frequency of allele $A$, although allele $B$ is the most common in both breeds. Allele $B$ was the most prevalent NRAMPI allele reported by Sun et al. [36] and it was found to be fixed in some Chinese breeds and the most common in improved breeds such as Large White and Landrace as well as Berkshire and Hampshire. Allele $A$ had the next highest frequency, and was reported only in the white breeds [36]. Allele $C$ was only found in the coloured breeds Hampshire, Duroc and Berkshire. Based on its history, the presence of the $C$ allele in Bazna (0.04) could originate from the Berkshire breed.

\subsection{DNA marker associated with coat colour}

\section{Melanocortin 1 Receptor (MC1R)}

$M C 1 R$ plays a central role in regulation of eumelanin and phaeomelanin synthesis in mammalian melanocytes and is encoded by the Extension coat colour locus $(E)$. Sequence analysis of $M C 1 R$ from different breeds revealed a total of four allelic variants corresponding to five different $E$ alleles [15]. 
As a result of testing for this gene we found that each breed appears to contain two allelic variants. This might be expected as the breeds are known to have been created from pigs of different origin, although selection for uniform colour normally takes place in breed development leading to fixation of alleles at this locus over time. Both breeds were found to carry the polymorphism associated with the $E^{P}$ or $E^{D 2}$ alleles. The $E^{P}$ allele is observed in the white breeds, but also in breeds that are spotted, belted or with white extremities represented by Pietrain, Hampshire and Berkshire [15]. The $E^{D 2}$ allele is associated with the dominant black colour of Hampshire pigs. With the test used it is not possible to distinguish the $E^{P}$ allele from the $E^{D 2}$ allele.

The mutation identified in $E^{P}$ results in loss of function of the receptor such that the coat colour of animals with this specific alteration would be expected to be red which fits with its presence in Mangalitsa. However, in Bazna it is assumed that the $E^{D 2}$ allele is present rather than the $E^{P}$ allele, based on the phenotype. The second allele found in Bazna is $E^{D 1}$, which is found in breeds such as the Large Black and Meishan. The allelic variants observed in this breed are consistent with the phenotype, which is a belted black breed. Both alleles are found in black breeds where the amount of non-black coat or skin is determined by other loci. The presence of the $E^{P}$ or $E^{D 2}$ alleles would be expected to have arisen from the Berkshire or Sattelschwein origin. It might also have arisen from Mangalitsa, however, if this was the case it might be expected that some animals homozygous for this allele would be red. Red pigs are not observed in the Turda Bazna herd. In the case of the white belt this has recently been shown to be an allele at the KIT locus in the pig [11] which will be dominant over the $M C 1 R$ alleles and we would predict that Bazna is fixed for the belt allele at the KIT locus.

For Red Mangalitsa the $E^{P}$ allele is present and the second allele identified is $E^{+}$, found in wild boar [15]. The presence of the $E^{+}$allele in Mangalitsa population is not a surprise, as it is closely related to the wild pig. The black striping of the body of Mangalitsa piglets in the first weeks of life, are in agreement with this assumption. The recent study of Giuffra et al. (2000) based on mtDNA demonstrates that Mangalitsa is genetically closer to the European wild boar than other domestic breeds. It is interesting that the recessive $e$ allele responsible for the red colour in Duroc is absent in this breed. Finally it is somewhat surprising to find two alleles at the $E$ locus in Mangalitsa as colour is relatively uniform, however, further studies will be necessary to resolve the situation in this breed.

\section{DISCUSSION}

Anonymous markers such as microsatellite loci have been recommended for the determination of genetic relationships or genetic distances between breeds [3]. An European Community project is currently underway to 
evaluate the genetic diversity of European pig resources (considering more than 50 breeds) using both microsatellites and AFLP markers. Analysing the distribution and amount of diversity in eleven breeds, Laval et al. [19] demonstrate that the contribution of four French local breeds is about half of the total diversity. The results from these projects will be a major contribution to the characterisation of the inventory of pig genetic resources. This should assist conservation efforts and also enlarge the panel of the genetic resources available to the pig industry and the scientific community.

However, breeds are typically described in terms of phenotypes and they reflect the purposes for which they have been kept in particular regions. It is therefore interesting to consider using gene markers that have been shown to be associated with important traits, such as those considered here, to analyse the diversity of a breed. The results reported here offer an interesting first description of the genetic structure and diversity of two important populations of rare breeds from Romania. The results are based on gene marker loci that are interesting for growth, disease resistance, prolificacy, meat quality and coat colour (see Introduction). We suggest that a diversity analysis of a population based simply on anonymous markers could be limited. We have proposed to take into consideration known causative mutations (e.g. CRC1), those mutations (e.g. ESR) associated with phenotypic variation and markers within interesting functional candidate genes. One possible drawback of this approach is that chance alone will contribute to different gene frequencies in the limited candidate genes used. However, given that most of the allele frequencies reported here were in the expected direction we do not believe this to be a significant problem.

Even though the populations are small and the gene markers are only a small selection of known genes, we have discovered a significant amount of variation in almost all of the characterised loci. The frequency of the alleles, confirmed in general the expectations based on the reported trait associations of the markers and specific breed phenotypes.

The $\chi^{2}$ contingency test used to estimate the differences between the breeds regarding gene frequency, suggests that differences in gene frequency may explain some of the phenotypic variation in several of the traits that differentiate the breeds. However without a joint evaluation of performance and genotype for each individual care must be taken in assigning associations. It is well-known that the loss of genetic variation from a population could affect important traits such as survival, growth, feed conversion, and normal development. Because both breeds are part of a conservation program this information could be used to assist in the preservation of a representative gene pool as an indicator of the genetic diversity of the populations.

This approach may also offer some limited evidence of the genetic information about the origin of the breeds (e.g. CRC1, MC1R, ESR). Furthermore, 
selection based on such genetic markers (e.g. CAST, PRLR or MC4R) may be useful for accelerating genetic progress in traditional breeds and established commercial lines. While local breeds are potentially a very important source of variation it is unlikely that many of them will be utilised in QTL studies because of the cost. Some of them could be an important reservoir of useful alleles, and efforts in finding new gene variants are underway in several endangered breeds, including the breeds considered in our study.

Today many of the breeds in danger of extinction have not even been properly characterised especially in developing countries. Molecular tools offer the means to characterise a breed not only in terms of genetic distance (e.g. with microsatellites) but also in terms of variation at interesting loci associated with phenotypes. Such an approach, illustrated here, will give more opportunity to elaborate an efficient strategy for conservation of breeds, maintaining their "useful" genetic diversity and providing important resources for possible new unique traits or for future scientific interest.

\section{ACKNOWLEDGEMENTS}

This work was financially supported by Romanian Ministry of Education, PIC International Group and the Iowa Agriculture and Home Economics Experimental Station, Ames, paper No. J-18926, project nos. 3148 and 3600, as well as by Hatch Act and State of Iowa funds. The Pig Biodiversity project is supported by the EC Biotechnology programme grant BIO4-CT98-0188. We thank Amy Vincent for permission to use unpublished results with the pig leptin receptor gene.

\section{REFERENCES}

[1] Baltay M., Magyarorszagi sertesfajtak es hibridek, Mezogazdasagi Kiado, Budapest, 1983.

[2] Barker J.S.F., Conservation of livestock breed diversity, Anim. Genet. Resource Inform. 25 (1999) 33-43.

[3] Barker J.S.F., Hill W.G., Bradley D., Nei M., Fries R., Wayne R.K., Measurement of domestic animal diversity (MoDAD): original working group report, FAO, Rome, 1998.

[4] Bidwell C.A., Ji S., Frank G.R., Cornelius S.G., Willis G.M., Spurlock M.E., Cloning and expression of the porcine obese gene, Anim. Biotech. 8 (1997) 191-206.

[5] Cellier M., Govoni G., Vidal S., Human natural resistance-associated macrophage protein: cDNA cloning, chromosomal mapping, genomic organization and tissue-specific expression, J. Exp. Med. 180 (1994) 1741-1752.

[6] Epstein H., Bichard M., Pig, in: Mason I.L.(Ed.), Evolution of domesticated animals, Longman, London and New York, 1984, pp. 145-162. 
[7] Ernst C.W., Robic A., Yerle M., Wang L., Rothschild M.F., Mapping of calpastatin and three microsatellites to porcine chromosome 2q2.1-q2.4., Anim. Genet. 29 (1998) 212-215.

[8] Friedman J.M., Halaas J.L., Leptin and the regulation of body weight in mammals, Nature 395 (1998) 763-769.

[9] Fujii J., Otsu K., Zorzato F., Leon S. de, Khanna V.K., Weiler P.E., O’Brien P.J., MacLennan D.H., Identification of a mutation in porcine ryanodine receptor associated with malignant hyperthermia, Science 253 (1991) 448-451.

[10] Gligor V., Radu A., Stanciulescu M., Zootehnia Romaniei - porcine, Editura Academiei, Bucuresti, 1969.

[11] Giuffra E., Evans G., Tornsten A., Wales R., Day A., Looft H., Plastow G., Andersson L., The Belt mutation in pigs is an allele at the dominant white (I/KIT) locus, Mamm. Genome 10 (1999) 1132-1136.

[12] Giuffra E., Kijas J.M.H., Amarger V., Carlborg O., Jeon J.-T., Andersson L., The origin of the domestic pig: independent domestication and subsequent introgression, Genetics 154 (2000) 1785-1791.

[13] Huszar D., Lynch C., Fairchild-Huntress V., Dunmore J., Fang Q., Berkemeier L., Gu W., Kesterson R., Boston B., Cone R., Smith F., Camfield L., Burn P., Lee F., Targeted disruption of the melanocortin-4 receptor results in obesity in mice, Cell 88 (1997) 131-141.

[14] Jiang Z-H, Gibson J.P., Genetic polymorphisms in the leptin gene and their association with fatness in four pig breeds, Mamm. Genome 10 (1999) 191-193.

[15] Kijas J.M.H., Wales R., Tornsten A., Chardon P., Moller M., Andersson L., Melanocortin receptor 1 (MC1R) mutations and coat color in pigs, Genetics 150 (1998) 1177-1185.

[16] Kim K.S., Larsen N., Short T.H., Plastow G.S., Rothschild M.F., A missense variant of the porcine melanocortin-4 receptor $(M C 4 R)$ gene is associated with fatness, growth, and feed intake traits, Mamm. Genome 11 (2000) 131-135.

[17] Klokowska J., Urbaniak B., Switonski M., High frequency of M307 ${ }^{\mathrm{A}}$ mutation at FUT1 locus causing resistance to oedema disease, in an autochtonous Polish pig breed, the Zlotnicka Spotted, J. Anim. Breed. Genet. 116 (1999) 519-524.

[18] Kretchmar D.H., Koohmaraie M., Mersmann H.J., Comparison of proteolytic variables in a lean and obese strain of pig at the ages of 2.5 and 7 months, Lab. Anim. Sci. 69 (1994) 617-624.

[19] Laval G., Iannuccelli N., Legault C., Milan D., Groenen M., Giuffra E., Andersson L., Nissen P., Jorgensen C., Beeckmann P., Geldermann H., Foulley J.L., Chevalet C., Ollivier L., Genetic diversity of eleven European pig breeds, Genet. Sel. Evol. 32 (2000) 187-203.

[20] Li C., Ioffe E., Fidahusein N., Connolly E., Friedman J.M., Absence of soluble leptin receptor in plasma from $\mathrm{dbPas} / \mathrm{dbPas}$ and other $\mathrm{db} / \mathrm{db}$ mice, J. Biol. Chem. 273 (1998) 10078-82.

[21] Meijerink E., Fries R., Vogeli P., Masabanda J., Wigger G., Stricker C., Neuenschwander S., Bertschinger H.U., Stranzinger G., Two alpha(1,2) fucosyltransferase genes on porcine chromosome 6q11 are closely linked to the blood group inhibitor (S) and Escherichia coli F18 receptor (ECF18R) loci, Mamm. Genome 8 (1997) 736-741. 
[22] Moldoveanu G., Fisteag I., Suicultura, Faculty of Veterinary Medicine Press, Bucharest, 1944.

[23] Ormandy C.J., Camus A., Barra J., Dammote D., Lucas B., Buteau H., Edery M., Brousse N., Babanet C., Binart F., Kelly P.A., Null mutation of the PRLR gene produces multiple reproductive defects in the mouse, Genec Dev. 1 (1997) 167-178.

[24] Pop T.M., Vlaic A., Moldovan I., Degan I., Bidianu A., Stabilirea parametrilor genetici a principalelor insusiri de carcasa la o populatie de porcine din rasa Bazna, in: Proceedings of Symposium-Realizari si perspective in zootehnie, XVIII-I (1992) 232-288.

[25] Pop T.M., Vlaic A., Moldovan I., Degan I., Spadaru F., Bidianu A., Studiul structurii genetice a unei populatii de suine din rasa Bazna pentru fundamentarea elaborarii si proiectarii planului de ameliorare, in: Proceedings of SymposiumRealizari si perspective in zootehnie, XVIII-I (1992) 289-293.

[26] Pop T.M., Vlaic A., Spadaru F., Moldovan I., Bidianu A., Cercetari privind structura genetica a unei populatii de suine din rasa Mangalita pentru fundamentarea elaborarii planului de ameliorare (I), in: Proceedings of Symposium-Realizari si perspective in zootehnie, XIX (1993) 186-192.

[27] Rothschild M.F., Plastow G.S., Advances in pig genomics and industry applications, AgBiotechNet (1999) 1-8.

[28] Rothschild M.F., Jacobson C., Vaske D.A., Tuggle C.K., Short T.H., Sasaki S., Eckardt G.R., McLaren D.G., A major gene for litter size in pigs, in: Proceedings of the 5th World Congress on Genetics Applied to Livestock Production, Guelph, Canada 17 (1994) 413.

[29] Rothschild M.F., Jacobson C., Vaske D., Tuggle C.K., Wang L., Short T., Sasaki S., Eckardt G.R., Vincent A., McLaren D.G., Southwood O., van der Steen H., Mileham A., Plastow G., The estrogen receptor locus is associated with a major gene influencing litter size in pigs, Proc. Natl. Acad. Sci. USA 93 (1996) 201-205.

[30] Ruane J., A critical review of the value of genetic distance studies in conservation of animal genetics resources, J. Anim. Breed. Genet. 116 (1999) 317-323.

[31] Sarac M., Jovanovic S., Gagrcin D., Distribution of the allele frequencies for some polymorphic enzyme and protein systems in two Yugoslav autochtonal pig breeds: Moravka and Mangulica, DAGENE Conference, Budapest, (1998) 35.

[32] Short T.H., Rothschild M.F., Southwood O.I., McLaren D.G., DeVries A.D., van der Steen H., Eckardt G.R., Tuggle C.K., Helm J., Vaske D.A., Mileham A.J., Plastow G.S., Effect of the estrogen receptor locus on reproduction and production traits in four commercial pig lines, J. Anim. Sci. 75 (1997) 31383142.

[33] Simon D.L., European approaches to conservation of farm animal genetic resources, Anim. Genet. Resources Inform. 25 (1999) 79-99.

[34] Stratil A., Peelman L., van Poucke M., Cepika S., A HinfI PCR-RFLP at the porcine leptin (LEP) gene, Anim. Genet. 28 (1997) 371-372.

[35] Stratil A., Kopecny M., Moser G., Schroffel J. Jr., Cepica S., HpaII and RsaI PCR-RFLPs within an intron of the porcine leptin receptor gene $(L E P R)$ and its linkage mapping, Anim. Genet. 29 (1998) 405-406. 
[36] Sun H.S., Wang L., Rothschild M.F., Tuggle C.K., Mapping of the natural resistance-associated macrophage protein 1 (NRAMPI) gene to pig chromosome 15, Anim. Genet. 29 (1998) 138-140.

[37] Tartaglia L.A., Dembski M., Weng X., Deng N., Culpepper J., Devos R., Richards G.J., Campfield L.A., Clark F.T., Deeds J., Muir C., Sanker S., Moriarty A., Moore K.J., Smutko J.S., Mays G.G., Woolf E.A., Monroe C.A., Tepper R.I., Identification and expression cloning of a leptin receptor, OB-R, Cell 83 (1995) $1263-1271$.

[38] Vaisse C., Clement K., Guy-Grand B., Froguel P., A frameshift mutation in human $M C 4 R$ is associated with a dominant form of obesity, Nat. Genet. 20 (1998) 113-114.

[39] Vidal S., Malo D., Vogan K., Skamene E., Gros P., Natural resistance to infection with intracellular parasites: isolation of a candidate for Bcg, Cell 73 (1993) 469-485.

[40] Vincent A.L., Wang L., Rothschild M.F., A restriction fragment length polymorphism in the porcine leptin receptor (LEPR) gene, J. Anim. Sci. 75 (1997) 2287.

[41] Vincent A. L., Evans G., Short T.H., Southwood O.I., Plastow G.S., Tuggle C.K., Rothschild M.F., The prolactin receptor gene is associated with increased litter size in pigs, in: Proceedings of the 6th World Congress on Genetics Applied to Livestock Production, Armidale, Australia, January 11-16, 1998.

[42] Yeo G.S., Farooqi I.S., Aminian S., Halsall D.J., Stanhope R.G., O'Rahilly S., A frameshift mutation in $M C 4 R$ associated with dominantly inherited human obesity, Nat. Genet. 20 (1998) 111-112.

[43] Zhang Y., Proenca R., Maffei M., Barone M., Leopold L., Friedman J.M., Positional cloning of the mouse obese gene and its human homologue, Nature 372 (1994) 425-432.

To access this journal on line: www.edpsciences.org 